a national scale, that is not very easy, and it is unlikely to be easier on the international plane. No less important, however, is the continuing support of the project until it is complete. The difficulty which international organizations have hitherto experienced in securing such support from year to year warrants little optimism that, without considerable raising of the standards of education, integrity and objectivity in political circles at all levels, we can hope for the co-operation and sustained support required for an attack on any major scientific or technological objective on the scale necessary in the modern world. Mr. Casey's proposals may, however, lead to a clearer understanding of what is possible if the individual nations are willing to pay the price; and they remind the scientist and technologist once more that he has responsibilities in this matter of education which are not simply professional but those of the citizen, too.

\section{LIFE OF HENRY ARMSTRONG}

Henry Edward Armstrong, 1848-1937

The Doyen of British Chemists and Pioneer of Technical Education. By Dr. J. Vargas Eyre. Pp. xix $+325+15$ plates. (London: Butterworths Scientific Publications, 1958.) $30 \mathrm{~s}$.

Tron

HIS biography of $\mathrm{H}$. E. Armstrong by one of his former pupils, Dr. Vargas Eyre, details the life of a vivid personality spanning the remarkably eventful years from 1848 to 1937 . He began the study of chemistry at the Royal College of Chemistry just before Hofmann left to return to Berlin. Edward Frankland succeeded to Hofmann's chair in 1865 when the idea of chemical valency was emerging and before Kekulé's benzene formula was generally known. But before Armstrong left the stage, valency had received an explanation in terms of the electron, and the three-dimensional structures of such complex compounds as the sterols had been elucidated. Truly a remarkable advance in a single life-time, and the recent synthesis of the diamond in a tetrahedral anvil at pressures of 100,000 atmospheres and temperatures near $2,000^{\circ} \mathrm{C}$. shows that the forward march continues.

In 1865 public sewers were almost unknown, and water pollution rampant. Frankland was one of those charged to tackle the problem and he set 'H. E.' to devise a method for estimating the pollution. During this period he attended lectures on geology by Ramsay, on physics by Tyndall and those on the place of science in education by Huxley. Later, Frankland urged him to go to Leipzig to work with Kolbe, and he did so in 1867 and remained nearly two and a half years working for his doctorate. On his first day in Leipzig, Kolbe suggested that Armstrong should examine the mixture formed on sulphonating phenol. Kolbe was also a forceful exponent of both attack and defence on chemical questions, and all the guiding principles in Armstrong's subsequent career had thus been fixed before he was twenty years old: purity of food and especially of milk and beer with the great problems of agriculture and health (Frankland), an abiding interest in geology (Ramsay), the life-long crusade on the teaching of science and its importance to industry (Huxley), the dominating role of sulphona. tion in his research work and the whole crowned by a dynamic character and a powerful debater (Kolbe). Apparently such characters no longer emerge from the mould in this plastic age.

On returning from Germany 'H. E.' started his teaching career at St. Bartholomew's Hospital and continued in this part-time post for twelve years. It is said he never received more than $£ 50$ a year for the work. Already in 1875 he was junior secretary of the Chemical Society, and when the senior W. H. Perkin retired he activated and came to dominate the Society after 1880. He was one of the first four professors appointed to the new City and Guilds Central College in 1884, and his research output began to mount. Many papers appeared on the sulphonation of naphthalene, others were on the terpenes, and particularly camphor. In 1888 he advanced the quinone theory to account for the colour of organic compounds, and both with pen and in debate he vigorously championed the role of water in electrolysis.

Possibly his many wide interests prevented him from making any great advances in the laboratory, but great credit is due to his school for producing chemists such as F. S. Kipping, A. Lapworth, T. M. Lowry, W. J. Pope, and W. P. Wynne among others. His forward vision embraced the importance of crystallography in chemistry and led him to appoint Henry Miers to lecture to his students on the subject.

The lack of suitable posts for chemists in industry at that time was reflected in the fact that he never had more than about a dozen senior students, and this probably influenced the authorities to close his chemistry department in 1911. After nearly thirty years of great service to the Central College he was given notice to quit without pension.

Armstrong was a fiery crusader who occupied the centre of the stage in many causes, but his advocacy of the teaching of science in schools also showed considerable statesmanship, as witness the paper he presented on the subject to the British Association in 1889 and its sequel in the successful trials of the heuristic method at St. Dunstan's College and Christ's Hospital. It is not too much to say that his work for education profoundly influenced science teaching in all Englishspeaking countries. It gives much food for thought that in spite of the urge for technical education and the application of science to industry in the fourth quarter of last century, these very problems are a matter of life and death to us in the third quarter of this century.

Dr. Eyre's account of Armstrong's life has clearly been a labour of love, and in the interest of the history of science it is well that it has been made. Perhaps it is rather long even for such an eventful life, and if much of the minor matter had been sacrificed Armstrong's great record of service to science and education would have shone all the clearer.

\section{G. R. Clewo}

\section{FRAUDULENT DOCUMENTS}

\section{Suspect Documents}

Their Scientific Examination. By Dr. Wilson R. Harrison. Pp. viii +583 . (London: Sweet and Maxwell, Ltd., 1958.) 84s. net.

T. HE book under review is a very important contribution to the published knowledge on the examination of suspect documents, particularly as it is the first complete review of the opinions of an acknowledged British expert on the subject. 